\title{
Acute Variation of Hematological Parameters during 622 km Ultra-Marathon
}

\author{
Kyung-A Shin ${ }^{1}$ and Young-Joo Kim ${ }^{2, \dagger}$ \\ ${ }^{1}$ Department of Clinical Laboratory Science, Shinsung University, Chungnam 31801, Korea \\ ${ }^{2}$ Department of Exercise Rehabilitaion Welfare, Sungshin University, Seoul 02844, Korea
}

To investigate the effects of strenuous physical exercise on commonly used hematological markers in subjects the intensive long running. Blood samples were obtained from nineteen participants in a $622 \mathrm{~km}$ ultra-marathon race before, $300 \mathrm{~km}$ and immediately after completion of the $622 \mathrm{~km}$ ultra-marathon. Samples were analyzed for total white cell count (WBC) and differential, total red cell count (RBC), hemoglobin, hematocrit, mean corpuscular volume (MCV), mean corpuscular hemoglobin (MCH), mean corpuscular hemoglobin concentration (MCHC), red cell distribution width (RDW), platelets, mean platelets volume (MPV), platelets distribution width (PDW). Significant increases were found in WBC, neutrophil and platelets at $622 \mathrm{~km}$ compared to the pre-race. RBC, hemoglobin and hematocrit decreased statistically significantly the race at $300 \mathrm{~km}$ and $622 \mathrm{~km}$ compared to pre-race. A wide range of hematological perturbations occur during $622 \mathrm{~km}$ ultra-marathon running but it was physiological changes within a reference range. The $622 \mathrm{~km}$ ultramarathon is less likely to cause clinically significant hematologic changes in athletes.

Key Words: Ultra-marathon, Hematological markers, Physiological changes

\section{서 론}

규칙적인 신체활동은 다양한 생리적 반응에 의한 긍정 적 효과가 있지만, 격렬한 운동은 저나트륨혈증, 골격근과 간세포 손상, 염증반응, 빈혈, 면역기능 저하 등 생화학 및 면역학적 변화를 일으킬 수 있다고 보고된다(Peters, 1997; Shin and Kim, 2012; Waśkiewicz et al., 2012; Drygas et al., 2014). 검사실에서 시행하는 혈액학적 검사는 임상 및 항 도핑(antidoping) 목적으로 스포츠 의학 분야에서 주목 받 고 있다(Lippi et al., 2010). 운동에 의한 혈액학적 변화를 조사하는 것은 데이터의 오역을 방지하고 임상적 유용성 을 향상시키기 위해 필요하지만, 인체에 미치는 잠재적
영향에 대한 정보는 부족하다(Banfi and Dolci, 2003). 지금 까지 운동상황에서 관찰된 혈액학적 변화는 $21 \mathrm{~km}$ 하프 마라톤 후 일시적인 백혈구, 호중구, 단구의 증가와 급성 호산구 감소증을 유발하며, 24시간 이내에 안정상태로 회 복된다고 보고된다(Lippi et al., 2010). Fallon 등(1999)은 $1,600 \mathrm{~km}$ 울트라 마라톤 직후 백혈구는 증가하나 헤모글 로빈, 적혈구 용적 백분율(packed cell volume, PCV), 림프 구 및 단구비율은 감소한다고 보고하였다. 장시간 고강도 운동에 의한 혈액학적 변화는 기계적 외상으로 인한 혈관 내 용혈, 적혈구 삼투압 및 산화적 손상, 잠혈에 의한 혈 액 손실의 가능성, 염증반응 등을 고려해야 한다(Smith, 1995; Shin and Kim, 2012).

$42.195 \mathrm{~km}$ 의 마라톤과 비교해 장거리를 달리는 울트라

\footnotetext{
* Received: June 11, 2017 / Revised: August 7, 2017 / Accepted: August 7, 2017

${ }^{\dagger}$ Corresponding author: Young-Joo Kim. Department of Exercise Rehabilitaion Welfare Soojung Campus, Sungshin University, 2 Bomun-Ro 34Da-Gil, Seongbuk-Gu, Seoul 02844, Korea.

Tel: +82-2-920-7942, Fax:+82-2-920-7942, e-mail: kyj87@sungshin.ac.kr

(C) The Korean Society for Biomedical Laboratory Sciences. All rights reserved.

(c) This is an Open Access article distributed under the terms of the Creative Commons Attribution Non-Commercial License (http://creativecommons.org/licenses/by-nc/3.0/) which permits unrestricted non-commercial use, distribution, and reproduction in any medium, provided the original work is properly cited.
} 
마라톤은 $100 \mathrm{~km}$ 이상을 달리는 경기로 규정되며, $622 \mathrm{~km}$ 국토종단 울트라 마라톤은 우리나라에서 진행되는 가장 긴 코스의 경기로 본 연구는 인간능력의 한계를 탐구하려 는 특별한 시도이다. 본 연구는 $622 \mathrm{~km}$ 울트라 마라톤 대 회에 출전한 주자들을 대상으로 경기전, $300 \mathrm{~km}$, 경기종료 직후에 혈액학적 지표 변화를 통해 잠재적인 의학적 합병 증의 평가와 치료에 도움이 되고자 하였다.

\section{재료 및 방법}

\section{$622 \mathrm{~km}$ 울트라 마라톤대회}

이 연구는 2015년 7월 5일 06시부터 7월 11일 12시까 지 총 150 시간 동안 대한 울트라 마라톤연맹 주관하에 시행한 $622 \mathrm{~km}$ 울트라 마라톤에 참여한 주자들을 대상으 로 하였다. 대회 출발지는 전남해남 땅끝 기념탑이며, 도 착지는 강원도 고성 출입국관리소였다. 울트라 마라톤 출 발 시 기온은 $29^{\circ} \mathrm{C}$, 습도는 $70 \%$ 였다. $622 \mathrm{~km}$ 울트라 마라 톤 참가자격은 한반도 횡단대회 $308 \mathrm{~km}$ 를 완주한 자, 제 주일주 $200 \mathrm{~km}$ 를 완주한 자, $622 \mathrm{~km}$ 울트라 마라톤을 중 도 포기하였으나 $200 \mathrm{~km}$ 이상을 제한시간 내에 주파한 자, $308 \mathrm{~km}$ 울트라 마라톤을 중도 포기하였으나 $200 \mathrm{~km}$ 이상 을 제한시간 내에 주파한 자, 대회일 기준으로 최근 2 년내 대한 울트라 마라톤연맹에서 공인한 대회에 $200 \mathrm{~km}$ 이상 완주한 자이다. $622 \mathrm{~km}$ 울트라 마라톤 주자들은 $50 \mathrm{~km}$ 단 위를 제한시간 내에 통과하여야 하며, 통과한 주자는 대 회 조직위원, 가족 및 지인이 준비한 텐트, 음식, 마사지 등을 제공받을 수 있었다. 그러나 차량 탑승은 부정행위 로 간주하였다. 대회 3 개월 전 대한 울트라 마라톤연맹 회 장에게 실험 방법 및 절차에 대해 설명을 한 후 대회 홈 페이지에서 인터넷 상으로 지원자를 모집하였다. 참가 의 향을 밝힌 자들을 선별하여 개인 메일로 연구 목적과 절 차에 대해 설명하였으며, 동의서를 받은 후 대회 1 개월 전부터 출발 1 주일 전까지 운동부하검사를 실시하였다. 이 연구는 인제대학교 상계백병원에서 IRB 심의를 받은 후 시행되었다(2015년 5월 6일, SGPAIK 2015-04-003-001).

\section{연구 대상자}

본 연구 대상자는 연구에 자발적으로 지원한 남성 총 28 명 중에서 $622 \mathrm{~km}$ 울트라 마라톤을 완주한 19명을 최 종 연구 대상자로 선정하였다. 연구 대상자에서 제외되는 기준은 $622 \mathrm{~km}$ 울트라 마라톤 완주에 실패한 자, 경기 규 정시간 내에 완주하지 못한 자, 안정 시 혈압이 140/90
$\mathrm{mmHg}$ 이상인 자, 협심증이나 심근경색증, 심장수술의 과 거력이 있는 심혈관계 질환자, 당뇨, 신장질환, 간질환자, 고혈압으로 약물 복용 중인 자는 제외하였다.

\section{혈액검사}

연구 대상자들의 혈액학적 지표를 분석하기 위하여 대 회 출발 전, 경기 중반지점인 $300 \mathrm{~km}$, 경기종료지점인 622 $\mathrm{km}$ 에서 채혈을 시행하였다. K2-EDTA tube (BD Vacutainer, USA)에 채혈한 전혈 검체로 LH 750 (Beckman Coulter, Miami, FL, USA) 자동화 장비를 이용하여 적혈구(red blood cell, RBC), 헤모글로빈(hemoglobin, $\mathrm{Hb}$ ), 헤마토크리트 (hematocrit, Hct), 적혈구 분포계수(red cell distribution width, RDW), 백혈구(white blood cell, WBC), 백혈구 백분 율(WBC differential count), 혈소판(platelet), 혈소판 용적치 (plateletcrit, PCT), 평균혈소판용적(mean platelet volume, $\mathrm{MPV}$ ), 혈소판 분포계수(platelet volume distribution width, $\mathrm{PDW}$ )를 측정하였으며, $\mathrm{Hb}$ 과 $\mathrm{Hct}$ 를 이용하여 평균적혈구 용적(mean corpuscular volume, $\mathrm{MCV}$ ), 평균적혈구혈색소 (mean corpuscular hemoglobin, $\mathrm{MCH}$ ), 평균적혈구혈색소농 도(mean corpuscular hemoglobin concentration, $\mathrm{MCHC}$ 를 산 출하였다. $\mathrm{MCV}$ 는 적혈구 한 개당 평균용적을 나타내는 지수로 (hematocrit $\%) /\left(\mathrm{RBC} \times 10^{6} / \mu \mathrm{L}\right) \times 10$ 으로, $\mathrm{MCH}$ 는 적혈구 한 개당 혈색소량으로(hemoglobin $\mathrm{g} / \mathrm{dL}) /(\mathrm{RBC} \times$ $\left.10^{6} / \mu \mathrm{L}\right) \times 10$ 으로, $\mathrm{MCHC}$ 는 적혈구 한 개당 평균혈색소 농도로 hemoglobin/ hematocrit $\times 100$ 으로 계산하였다.

\section{운동부하검사}

연구 대상자들의 유산소성 운동능력을 측정하기 위하여 트레드밀 운동부하검사(Quintion Co, U.S.A)는 3분마다 속 도와 경사도를 증가시키는 Bruce Protocol로 시행하였으며, Medtrack ST 55 (Quinton Instrument Co., Boston, USA) 트레 드밀 장비를 사용하여 측정하였다. 운동부하검사 종료시 점은 심박수가 더 이상 증가하지 않고 운동자각도(RPE; rating of perceived exertion, Borg's Scale)가 17 이상일 경우 로 하였으며, 미국심장학회(America College of Cardiology, $\mathrm{ACC}$ ) 및 미국심장협회(American Heart Association, AHA)의 지침에 따라 검사하였다(Gibbons et al., 2002). 모든 피험자 는 검사 전 의자에 앉아 안정을 취한 후 안정 시 심박수 와 혈압을 측정하였으며, 혈압은 수은 혈압계로 측정하였 다. 운동 중 운동자각도와 혈압은 매 stage와 테스트 직후 및 회복기 동안에 측정하였다. 운동부하검사를 통해 안정 시 심박수(resting heart rate, RHR). 최대 심박수(maximum 
heart rate, MHR), 안정시 수축기혈압(resting systolic blood pressure, RSBP) 및 이완기혈압(resting diastolic blood pressure, $\mathrm{RDBP}$ ), 최대 수축기혈압(maximum systolic blood pressure, MSBP) 및 이완기혈압(maximum diastolic blood pressure, $\mathrm{MDBP})$ 을 기록하였다. 운동부하 검사용 심전도 검사기 Q4500 (Quinton Instrument Co., Boston, USA) 및 호흡가스 분석기 QMC (Quinton Instrument Co., Boston, USA)를 이 용하여 최대산소섭취량(maximum oxygen consumption, $\mathrm{VO}_{2} \mathrm{max}$ )을 측정하였으며, 체질량지수(body mass index, $\mathrm{BMI})\left(\mathrm{kg} / \mathrm{m}^{2}\right)$ 는 몸무게 $(\mathrm{kg}) /\left[\right.$ 신장 $\left.\left(\mathrm{m}^{2}\right)\right]$ 으로 계산하였다.

\section{자료처리방법}

본 연구의 통계분석은 SPSS Windows 21.0 (IBM, Armonk, USA) 프로그램을 이용하였다. $622 \mathrm{~km}$ 울트라 마라톤 경 기 전, $300 \mathrm{~km}$ 지점, $622 \mathrm{~km}$ 종료시점에서의 구간별 기술 통계치(평균, 표준편차)를 구하였다. 3 구간에서 시기별 혈 액학적 지표의 차이를 비교하기 위해 단일변량 반복측정 분산분석(one way repeated measures ANOVA)을 실시하였 으며, 사후검정 방법으로 Bonferroni를 적용하였다. 본 연 구의 통계학적 유의수준은 $P<0.05$ 로 설정하였다.

\section{결 과}

\section{$622 \mathrm{~km}$ 울트라 마라톤 참가자의 특성}

$622 \mathrm{~km}$ 울트라 마라톤대회에 출전한 주자들의 특성은 Table 1에 제시된 바와 같이 평균 연령은 53.00土4.36세, 평균 신장은 $171.32 \pm 3.83 \mathrm{~cm}$, 평균 체중은 $69.63 \pm 3.89 \mathrm{~kg}$, 평균 체질량지수는 $23.65 \pm 1.32 \mathrm{~kg} / \mathrm{m}^{2}$ 이었다. 평균 $\mathrm{RHR}$
은 $65.47 \pm 6.80 \mathrm{bpm}$ 이었으며, 운동부하검사 시 평균 $\mathrm{MHR}$ 은 $177.00 \pm 5.93 \mathrm{bpm}$ 이었다. 평균 $\mathrm{RSBP}$ 와 $\mathrm{RDBP}$ 는 각각 $126.05 \pm 8.78 \mathrm{mmHg}, 80.21 \pm 5.82 \mathrm{mmHg}$ 이었다. 운동부하검 사 시 평균 $\mathrm{MSBP}$ 와 $\mathrm{MDBP}$ 는 각각 $219.89 \pm 17.37 \mathrm{mmHg}$, $78.32 \pm 8.31 \mathrm{mmHg}$ 이었다. 평균 최대산소섭취량은 49.65 $\pm 5.76 \mathrm{~mL} / \mathrm{kg} / \mathrm{min}$ 이었으며, 평균 경기시간은 $8,110.26 \pm$ $1,312.05$ 분 이었다.

\section{$622 \mathrm{~km}$ 울트라 마라톤 구간별 백혈구 관련 지표의 변화}

$622 \mathrm{~km}$ 울트라 마라톤대회에 출전한 주자들을 대상으로

Table 1. Subject characteristics ( $\mathrm{N}=19)$

\begin{tabular}{lc}
\hline \multicolumn{1}{c}{ Variables } & Mean \pm SD \\
\hline Age (year) & $53.00 \pm 4.36$ \\
Height $(\mathrm{cm})$ & $171.32 \pm 3.83$ \\
Weight $(\mathrm{kg})$ & $69.63 \pm 3.89$ \\
BMI $\left(\mathrm{kg} / \mathrm{m}^{2}\right)$ & $23.65 \pm 1.32$ \\
RHR $(\mathrm{bpm})$ & $65.47 \pm 6.80$ \\
MHR (bpm) & $177.00 \pm 5.93$ \\
RSBP $(\mathrm{mmHg})$ & $126.05 \pm 8.78$ \\
RDBP $(\mathrm{mmHg})$ & $80.21 \pm 5.82$ \\
MSBP $(\mathrm{mmHg})$ & $219.89 \pm 17.37$ \\
MDBP $(\mathrm{mmHg})$ & $78.32 \pm 8.31$ \\
VO ${ }_{2} \mathrm{max}(\mathrm{mL} / \mathrm{kg} / \mathrm{min})$ & $49.65 \pm 5.76$ \\
Race time $(\mathrm{min})$ & $8,110.26 \pm 1,312.05$ \\
\hline
\end{tabular}

Abbreviations: BMI, body mass index; RHR, resting heart rate; MHR, maximum heart rate; RSBP, resting systolic blood pressure; RDBP, resting diastolic blood pressure; MSBP, maximum systolic blood pressure; MDBP, maximum diastolic blood pressure.

Table 2. Changes in WBC parameters during the $622 \mathrm{~km}$ ultra-marathon

\begin{tabular}{lcccc}
\hline \hline \multicolumn{1}{c}{ Variables } & Pre-race & $300 \mathrm{~km}$ & $622 \mathrm{~km}$ & $P$-value \\
\hline WBC $\left(\times 10^{3}\right.$ cells $\left./ \mu \mathrm{L}\right)$ & $6.20 \pm 0.99$ & $9.79 \pm 2.06^{*}$ & $8.95 \pm 2.29^{*}$ & $<0.001$ \\
WBC differential count & & & & $<0.001$ \\
Neutrophil (\%) & $51.31 \pm 10.09$ & $71.20 \pm 7.90^{*}$ & $72.77 \pm 6.53^{*}$ & $<0.001$ \\
Lymphocyte (\%) & $38.40 \pm 8.76$ & $19.43 \pm 6.52^{*}$ & $17.66 \pm 5.26^{*}$ & 0.053 \\
Monocyte (\%) & $6.46 \pm 1.27$ & $7.58 \pm 1.64$ & $7.42 \pm 2.03$ & 0.042 \\
Eosinophil (\%) & $3.21 \pm 2.50$ & $1.49 \pm 1.17^{*}$ & $1.83 \pm 1.54$ & $<0.001$ \\
Basophil (\%) & $0.60 \pm 0.25$ & $0.27 \pm 0.13^{*}$ & $0.28 \pm 0.14^{*}$ & \\
\hline
\end{tabular}

Calculated by one way repeated measures ANOVA and Bonferroni test.

Values are presented as mean $\pm \mathrm{SD}$.

Abbreviations: WBC, white blood cell.

*; Significantly different from Pre-race at $P<0.05$. 
Table 3. Changes in RBC and RBC indices during the $622 \mathrm{~km}$ ultra-marathon

\begin{tabular}{lcccc}
\hline \hline \multicolumn{1}{c}{ Variables } & Pre-race & $300 \mathrm{~km}$ & $622 \mathrm{~km}$ & $P$-value \\
\hline $\mathrm{RBC}\left(\times 10^{6}\right.$ cells $\left./ \mu \mathrm{L}\right)$ & $4.60 \pm 0.42$ & $4.28 \pm 0.36^{*}$ & $4.13 \pm 0.34^{* \dagger}$ & $<0.001$ \\
$\mathrm{Hb}(\mathrm{g} / \mathrm{dL})$ & $14.10 \pm 1.54$ & $13.05 \pm 1.44^{*}$ & $12.52 \pm 1.35^{* \dagger}$ & $<0.001$ \\
$\mathrm{Hct}(\%)$ & $40.12 \pm 3.50$ & $37.80 \pm 3.36^{*}$ & $36.96 \pm 3.40^{*}$ & $<0.001$ \\
$\mathrm{MCV}(\mathrm{fL})$ & $87.38 \pm 6.01$ & $88.36 \pm 6.23^{*}$ & $89.63 \pm 6.33^{* \dagger}$ & $<0.001$ \\
$\mathrm{MCH}(\mathrm{pg})$ & $30.69 \pm 2.71$ & $30.49 \pm 2.66^{*}$ & $30.35 \pm 2.64^{*}$ & $<0.001$ \\
$\mathrm{MCHC}(\mathrm{g} / \mathrm{dL})$ & $35.07 \pm 1.25$ & $34.45 \pm 1.20^{*}$ & $33.82 \pm 1.07^{* \dagger}$ & $<0.001$ \\
$\mathrm{RDW}(\%)$ & $13.06 \pm 1.46$ & $13.19 \pm 1.49$ & $13.36 \pm 1.97$ & 0.144 \\
\hline
\end{tabular}

Calculated by one way repeated measures ANOVA and Bonferroni test.

Values are presented as mean \pm SD.

Abbreviations: RBC, red blood cell; $\mathrm{Hb}$, hemoglobin; Hct, hematocrit; $\mathrm{MCV}$, mean corpuscular volume; $\mathrm{MCH}$, mean corpuscular hemoglobin; MCHC, mean corpuscular hemoglobin concentration; RDW, red cell distribution width.

*; Significantly different from Pre-race at $P<0.05, \dagger$; Significantly different from $300 \mathrm{~km}$ at $P<0.05$.

Table 4. Changes in platelet parameters during the $622 \mathrm{~km}$ ultra-marathon

\begin{tabular}{lcccr}
\hline \hline \multicolumn{1}{c}{ Variables } & Pre-race & $300 \mathrm{~km}$ & $622 \mathrm{~km}$ & $P$-value \\
\hline Platelet $\left(\times 10^{3}\right.$ cells $\left./ \mu \mathrm{L}\right)$ & $225.78 \pm 53.12$ & $225.31 \pm 47.78$ & $240.26 \pm 48.66^{* \dagger}$ & 0.011 \\
PCT $(\%)$ & $0.23 \pm 0.05$ & $0.23 \pm 0.04$ & $0.26 \pm 0.04^{* \dagger}$ & $<0.001$ \\
MPV (fL) & $10.44 \pm 0.92$ & $10.53 \pm 0.81$ & $11.00 \pm 0.86^{* \dagger}$ & $<0.001$ \\
PDW (fL) & $12.51 \pm 2.19$ & $12.48 \pm 1.78$ & $12.82 \pm 1.67$ & 0.144 \\
\hline
\end{tabular}

Calculated by one way repeated measures ANOVA and Bonferroni test.

Values are presented as mean $\pm \mathrm{SD}$.

Abbreviations: PCT, plateletcrit; MPV, mean platelet volume, PDW, platelet distribution width.

*; Significantly different from Pre-race at $P<0.05$, $\dagger$; Significantly different from $300 \mathrm{~km}$ at $P<0.05$.

경기 전, $300 \mathrm{~km}$ 지점, $622 \mathrm{~km}$ 경기종료 직후의 혈액학적 지표의 변화를 알아보고자 하였으며, 그 결과 구간별 백 혈구 관련 지표의 변화는 Table 2에 제시된 바와 같다. 백 혈구는 경기 전보다 $300 \mathrm{~km}$ 지점과 $622 \mathrm{~km}$ 지점에서 유 의하게 높았다 $(P<0.001)$. 백혈구수 백분율에서 호중구는 경기 전보다 $300 \mathrm{~km}$ 지점과 $622 \mathrm{~km}$ 지점에서 유의하게 높았으며 $(P<0.001)$, 림프구와 호염기구는 경기 전보다 $300 \mathrm{~km}$ 지점과 $622 \mathrm{~km}$ 지점에서 유의하게 낮았다(각각 $P<0.001)$. 또한 호산구는 경기 전보다 $300 \mathrm{~km}$ 지점에서 유의하게 낮았으나 $(P=0.042)$, 단구는 마라톤 구간별 유의 한 차이가 없었다.

\section{$622 \mathrm{~km}$ 울트라 마라톤 구간별 적혈구 관련 지표의 변화}

적혈구와 $\mathrm{Hb}$ 은 경기 전보다 $300 \mathrm{~km}$ 지점과 $622 \mathrm{~km}$ 지 점에서 낮았으며, $622 \mathrm{~km}$ 는 $300 \mathrm{~km}$ 지점보다 낮았다(각 각 $P<0.001) . \mathrm{Hct}$ 는 경기 전보다 $300 \mathrm{~km}$ 지점과 $622 \mathrm{~km}$
지점에서 낮게 나타났다 $(P<0.001) . \mathrm{MCV}$ 는 경기 전보다 $300 \mathrm{~km}$ 지점과 $622 \mathrm{~km}$ 지점에서 높았으며, $622 \mathrm{~km}$ 지점은 $300 \mathrm{~km}$ 지점보다 높았다 $(P<0.001)$. 그러나 $\mathrm{MCHC}$ 는 경기 보다 $300 \mathrm{~km}$ 와 $622 \mathrm{~km}$ 지점에서 낮았으며, $622 \mathrm{~km}$ 지점은 $300 \mathrm{~km}$ 지점보다 낮게 나타났다 $(P<0.001)$. 또한 $\mathrm{MCH}$ 는 경기 전보다 $300 \mathrm{~km}$ 와 $622 \mathrm{~km}$ 지점에서 통계적으로 유의 하게 낮았으나 $(P<0.001), \mathrm{RDW}$ 는 마라톤 구간별 차이가 없었다(Table 3).

\section{$622 \mathrm{~km}$ 울트라 마라톤 구간별 혈소판 관련 지표의 변화}

혈소판수 $(P=0.011)$ 와 PCT $(P<0.001), \mathrm{MPV}(P<0.001)$ 는 경기 전보다 $622 \mathrm{~km}$ 지점에서 높았으며, $300 \mathrm{~km}$ 지점보다 도 $622 \mathrm{~km}$ 지점에서 높게 나타났다. 그러나 $\mathrm{PDW}$ 는 구간 별 유의한 차이가 없었다(Table 4). 


\section{고 찰}

마라톤은 인체에 과도한 부담을 주어 선수의 2 8\% 정도는 경기 중 또는 경기 후에 전해질 불균형, 근골격계 상해 및 심폐기능 합병증 등으로 의료진의 진료를 받는 것으로 보고된다(Crouse and Beattie, 1996; Roberts, 2000; Sanchez et al., 2006; Mohseni et al., 2011). 또한 마라톤 경기 에 의해 백혈구 증가와 혈소판, 적혈구, $\mathrm{Hb}, \mathrm{Hct}$ 등의 다양 한 혈액학적 변화를 보이지만, 이러한 지표는 주자들의 특성, 채혈시점, 경기수행 능력 및 거리, 운동강도, 환경 적 요인 등으로 인해 다양한 결과를 나타낸다(Kratz et al., 2002; Spiropoulos and Trakada, 2003; Traiperm et al., 2013; Lippi et al., 2014; Martin et al., 2015).

본 연구에서는 우리나라에서 시행되는 가장 긴 코스의 $622 \mathrm{~km}$ 국토종단 울트라 마라톤이 혈액학적 지표 변화에 미치는 영향을 알아보고자 하였다. 그 결과 경기 전보다 $300 \mathrm{~km}$ 지점과 경기직후에 호중구 증가 및 림프구 감소 에 따른 백혈구수 증가를 보였다. 울트라 마라톤은 넓은 범위의 혈액학적 지표 변화를 나타내는데, 특히 백혈구 상 승은 대부분 호중구 증가증(neutrophilia)에 의한 것으로 일 시적인 면역기능 저하가 나타난 것으로 생각된다(Pyne, 1994; Natale et al., 2003; Smith et al., 2004). 이는 운동에 의 한 생체부하 및 스트레스로 유발된 정상적인 급성기 반응 으로 감염이나 질환의 지표와 혼돈해서는 안될 것으로 생 각된다(Fallon et al., 1999). 운동에 의한 호중구 증가는 국 소적으로 손상된 조직에서 분비되는 카테콜아민, 코티졸 과 같은 호르몬이나 체온 변화 및 혈류 증가에 따른 염증 반응에 의해 유발되는 것으로 제시된다(Pyne, 1994; Natale et al., 2003; Nieman, 2007; Lippi et al., 2010). 본 연구에서 $622 \mathrm{~km}$ 울트라 마라톤 직후 4명의 대상자에게서 백혈구 수가 참고범위를 벗어났으나, 감염의 징후는 없었다.

$\mathrm{Wu}$ 등(2004)은 24시간 울트라 마라톤 직후 빈혈 지표 인 적혈구, $\mathrm{Hb}, \mathrm{Hct}$ 는 정상이었으나, 경기 이틀 후에 감소 한다고 보고하였다. 또한 적혈구와 $\mathrm{Hb}$ 은 탈수와 혈장용 적 감소로 마라톤 초기에는 상승하다가 적혈구 손상에 의 해 경기종료 후 감소하는 것으로 보고되며(Martin et al., 2015), 이러한 현상을 스포츠 빈혈이라 한다(Eichner, 1986). 스포츠 빈혈은 만성적 희석 상태(chronic dilutional state)로 써 물리적 외상에 의한 혈관내 용혈뿐만 아니라 적혈구의 산화적 손상 때문에 유발된다(Eichner, 1986; Smith, 1995).

본 연구결과 적혈구와 $\mathrm{Hb}$ 은 경기 전보다 달리는 거리
가 길어질수록 낮아졌으며, Hct는 경기 전보다 $300 \mathrm{~km}$ 지 점과 $622 \mathrm{~km}$ 지점에서 낮았다. 정상적으로 적혈구의 평균 수명은 120 일로 매일 약 $1 \%$ 씩 새로운 세포로 교체된다 (Wu et al., 2004). 마라톤과 같은 지구력 운동에 의한 지속 적인 발바닥 충격(foot strike)은 용혈의 원인이 되어 적혈 구 교체율(turnover rate)을 증가시키지만, 새로운 적혈구 는 오래된 적혈구보다 산소운반에 더 효율적일 수 있다 고 보고된다(Smith, 1995; Jordan et al., 1998). 한편, Lippe 등 (2010)은 하프 마라톤 종반에 적혈구의 크기를 의미하는 $\mathrm{MCV}$ 의 유의한 증가를 보고하였으나, 24 시간 울트라 마 라톤 경기 전후에 $\mathrm{MCV}$ 의 차이가 없다는 결과도 보고된 다(Wu et al., 2004). 본 연구에서는 주행거리가 길어질수록 $\mathrm{MCV}$ 와 $\mathrm{MCHC}$ 는 비례하여 증가하였으며, $\mathrm{MCH}$ 는 경기 전보다 $300 \mathrm{~km}$ 와 경기직후 유의한 증가를 보여 스포츠 빈혈에 적혈구 크기 및 헤모글로빈 양이 원인인 것으로 보인다. 그러나 적혈구 용혈과 관련된 haptoglobin, 망상적 혈구수, 철분관련 검사가 요구되며, 향후 $622 \mathrm{~km}$ 울트라 마라톤에서 혈액학적 변인들의 회복기 반응에 관한 연구 가 필요하리라 생각된다.

마라톤과 같은 고강도 지구력 운동에 의해 혈소판과 MPV의 증가가 보고되며(Wu et al., 2004; Lippi et al., 2014), 본 연구결과에서도 $622 \mathrm{~km}$ 울트라 마라톤 직후 혈소판과 $\mathrm{MPV}$ 가 증가하였다. 전통적으로 $\mathrm{MPV}$ 의 증가는 혈소판 과반응성(platelet hyperreactivity)을 반영하는데, 최근 메타 분석에서 급성 심근경색, 심근경색 후 사망률 및 관상동 맥 혈관 성형술 후 재협착과의 관련성이 확인되었다(Chu et al., 2010; Gasparyan et al., 2011). 그러나 Lippi 등은 혈소 판과 $\mathrm{MPV}$ 가 경기 이후 3 시간의 회복기 동안에 안정 시 수치로 회복됨을 보고하여 혈소판 용적 증가가 지속적 운 동에 의한 생리학적 변동임을 유추할 수 있으나, 응고장 애와 관련된 추가검사가 필요하겠다(Lippi et al., 2014).

결론적으로 $622 \mathrm{~km}$ 울트라 마라톤은 호중구 증가에 의 한 백혈구수 증가와 적혈구 및 $\mathrm{Hb}$ 의 감소, 혈소판 증가 를 유발하였다. 이러한 결과는 참고범위 내에서의 생리학 적 변화로 $622 \mathrm{~km}$ 울트라 마라톤이 선수들에게 임상적으 로 중요한 혈액학적 변화를 일으킬 위험은 낮은 것으로 나타났다.

\section{CONFLICT OF INTEREST}

The authors have no conflicts of interest to disclose. 


\section{REFERENCES}

Banfi G, Dolci A. Preanalytical phase of sport biochemistry and haematology. Journal of Sports Medicine and Physical Fitness. 2003. 43: 223-230.

Chu SG, Becker RC, Berger PB, Bhatt DL, Eikelboom JW, Konkle B, Mohler ER, Reilly MP, Berger JS. Mean platelet volume as a predictor of cardiovascular risk: a systematic review and meta-analysis. Journal of Thrombosis and Haemostasis 2010. 8: $148-156$.

Crouse B, Beattie K. Marathon medical services: strategies to reduce runner morbidity. Medicine and Science in Sports and Exercise. 1996. 28: 1093-1096.

Drygas W, Rębowska E, Stępień E, Golański J, Kwaśniewska M. Biochemical and hematological changes following the 120km open-water marathon swim. Journal of Sports Science and Medicine. 2014. 13: 632-637.

Eichner ER. The Anemias of Athletes. Physician and Sportsmedicine. 1986. 14: 122-130.

Fallon KE, Sivyer G, Sivyer K, Dare A. Changes in haematological parameters and iron metabolism associated with a 1600 kilometre ultramarathon. British Journal of Sports Medicine. 1999. 33: 27-31

Gasparyan AY, Ayvazyan L, Mikhailidis DP, Kitas GD. Mean platelet volume: a link between thrombosis and inflammation? Current Pharmaceutical Design. 2011. 17: 47-58.

Gibbons RJ, Balady GJ, Bricker JT, Chaitman BR, Fletcher GF, Froelicher VF, Mark DB, McCallister BD, Mooss AN, O'Reilly MG, Winters WL, Gibbons RJ, Antman EM, Alpert JS, Faxon DP, Fuster V, Gregoratos G, Hiratzka LF, Jacobs AK, Russell RO, Smith SC. American College of Cardiology/American Heart Association Task Force on Practice Guidelines. Committee to Update the 1997 Exercise Testing Guidelines. ACC/ AHA 2002 guideline update for exercise testing: summary article. A report of the American College of Cardiology/ American Heart Association Task Force on Practice Guidelines (Committee to Update the 1997 Exercise Testing Guidelines). Journal of the American College of Cardiology. 2002. 40: 1531 -1540 .

Jordan J, Kiernan W, Merker HJ, Wenzel M, Beneke R. Red cell membrane skeletal changes in marathon runners. International Journal of Sports Medicine. 1998. 19: 16-19.

Kratz A, Lewandrowski KB, Siegel AJ, Chun KY, Flood JG, Van
Cott EM, Lee-Lewandrowski E. Effect of marathon running on hematologic and biochemical laboratory parameters, including cardiac markers. American Journal of Clinical Pathology. 2002. 118: 856-863.

Lippi G, Banfi G, Montagnana M, Salvagno GL, Schena F, Guidi GC. Acute variation of leucocytes counts following a halfmarathon run. International Journal of Laboratory Hematology. 2010. 32: 117-121.

Lippi G, Salvagno GL, Danese E, Tarperi C, Guidi GC, Schena F. Variation of red blood cell distribution width and mean platelet volume after moderate endurance exercise. Advances in Hematology. 2014. 192173.

Martin TG, Pata RW, D'Addario J, Yuknis L, Kingston R, Feinn R. Impact of age on haematological markers pre- and postmarathon running. Journal of Sports Sciences. 2015. 33: 1988 $-1997$.

Mohseni M, Silvers S, McNeil R, Diehl N, Vadeboncoeur T, Taylor W, Shapiro S, Roth J, Mahoney S. Prevalence of hyponatremia, renal dysfunction, and other electrolyte abnormalities among runners before and after completing a marathon or half marathon. Sports Health. 2011. 3: 145-151.

Natale VM, Brenner IK, Moldoveanu AI, Vasiliou P, Shek P, Shephard RJ. Effects of three different types of exercise on blood leukocyte count during and following exercise. Sao Paulo Medical Journal. 2003. 121: 9-14.

Nieman DC. Marathon training and immune function. Sports Medicine. 2007. 37: 412-415.

Peters EM. Exercise, immunology and upper respiratory tract infections. International Journal of Sports Medicine. 1997. 18: S69-77.

Pyne DB. Regulation of neutrophil function during exercise. Sports Medicine. 1994. 17: 245-258.

Roberts WO. A 12-yr profile of medical injury and illness for the Twin Cities Marathon. Medicine and Science in Sports and Exercise . 2000. 32: 1549-1555.

Sanchez LD, Corwell B, Berkoff D. Medical problems of marathon runners. American Journal of Emergency Medicine. 2006. 24: 608-615.

Shin KA, Kim YJ. Comparison of the Muscle Damage and Liver Function in Ultra-Marathon Race $(100 \mathrm{~km})$ by Sections. Biomedical Science Letters. 2012. 18: 276-282.

Smith JA. Exercise, training and red blood cell turnover. Sports Medicine. 1995. 19: 9-31.

Smith JE, Garbutt G, Lopes P, Tunstall Pedoe D. Effects of prolonged strenuous exercise (marathon running) on biochemical 
and haematological markers used in the investigation of patients in the emergency department. British Journal of Sports Medicine. 2004. 38: 292-294

Spiropoulos K, Trakada G. Hematologic and biochemical laboratory parameters before and after a marathon race. Lung. 2003. 181: 89-95.

Traiperm N, Gatterer H, Burtscher M. Plasma electrolyte and hematological changes after marathon running in adolescents. Medicine and Science in Sports and Exercise. 2013. 45: 1182 $-1187$.

Waśkiewicz Z, Kłapcińska B, Sadowska-Krępa E, Czuba M, Kempa

K, Kimsa E, Gerasimuk D. Acute metabolic responses to a 24-h ultra-marathon race in male amateur runners. European Journal of Applied Physiology. 2012. 112: 1679-1688.

Wu HJ, Chen KT, Shee BW, Chang HC, Huang YJ, Yang RS. Effects of $24 \mathrm{~h}$ ultra-marathon on biochemical and hematological parameters. World Journal of Gastroenterology. 2004. 10: $2711-2714$.

https://doi.org/10.15616/BSL.2017.23.3.208

Cite this article as: Shin KA, Kim YJ. Acute Variation of Hematological Parameters during $622 \mathrm{~km}$ UltraMarathon. Biomedical Science Letters. 2017. 23: 208-214. 